\title{
Greenland
}

\section{A post-Danish sovereign nation state in the making}

Gad, Ulrik Pram

Published in:

Cooperation and Conflict

DOI:

$10.1177 / 0010836713514151$

Publication date:

2014

Document version

Peer reviewed version

Citation for published version (APA):

Gad, U. P. (2014). Greenland: A post-Danish sovereign nation state in the making. Cooperation and Conflict, 49(1), 98-118. https://doi.org/10.1177/0010836713514151 


\author{
Ulrik Pram Gad (2014) \\ Centre for Advanced Security Theory \\ Department of Political Science \\ University of Copenhagen
}

\title{
Greenland: a post-Danish sovereign nation state in the making Cooperation \& Conflict 49(1):98-118 \\ special issue on 'Postimperial Sovereignty Games in Norden' \\ Please refer to published version for referencing and citing: http://cac.sagepub.com/content/49/1/98
}

\begin{abstract}
The relationship between Greenland and the EU can best be understood by exploring the development from Danish colonialism to a future independent Greenlandic state. In 1985, Greenland became the first territory ever to leave the EEC when it opted for status as an 'overseas country or territory'. The manner in which Greenland had to follow Denmark into the EEC in 1973 - whereby Greenlanders saw control over their fisheries move from distant Copenhagen to evenmore-distant Brussels - was pivotal for the Greenlandic demands for home rule which succeeded in 1979 and made the 1985 withdrawal possible. On 25 November 2008, a majority of the people of Greenland voted in favour of enhanced home rule - 'self-government' - still within formal Danish sovereignty. Denmark and Greenland alike are preparing for a future envisioned as involving climate change, intensive raw material extraction, new transportation corridors and new claims to sovereignty over the Arctic. Greenland uses this imagined future as a way of enhancing its subjectivity, not the least when dealing with the EU. This article analyses how the Greenlandic selfunderstanding as being on the way to sovereignty - and the tensions involved - structure the triangular relationship between the EU, Greenland and Denmark. The article concludes that the visions of sovereign equality might, on the one hand, create greater expectations than Greenland will immediately be able to live up to - at home and in the EU. On the other hand, the representation of the Greenland-EU relationship as one of sovereign equality - present and future might just be able to provoke the resources necessary to make the dream come true.
\end{abstract}

\section{Keywords}

Norden; Empire; Greenland; European Union; Sovereignty Games

\section{Author Biography}

Ulrik Pram Gad is a Postdoctoral Researcher at the Centre for Advanced Security Studies, University of Copenhagen, Denmark. From 1998 to 2002, he worked for the Greenland Home Rule Government as a management assistant in the Prime Minister's Office and in the Department of Foreign Affairs. His current research focuses on the identity politics of Danish-Muslim relations and on the postcolonial relationship between Greenland and Denmark. Publications include European Integration and Postcolonial Sovereignty Games (with R Adler-Nissen (eds), Routledge 2012), and 'Postcolonial Identity in Greenland?' in Journal of Language and Politics (2009).

\section{Corresponding author:}

Ulrik Pram Gad, Center for Advanced Security Theory, Department of Political Science, University of Copenhagen, Øster Farimagsgade 5A, DK-1353 Copenhagen K, Denmark. Email: upg@ifs.ku.dk 


\section{The place of the EU in Greenlandic sovereignty games}

The tidal wave of decolonization began with giant India immediately after World War II and petered out in the 1970s and 1980s as a number of small islands and archipelagos like Dominica, Saint Kitts and Nevis, Vanuatu and Micronesia acquired independence. The wave left behind a number of very small polities in terms of population size (Baldacchino, 2012). Small size poses specific challenges in terms of relying on outside resources - human, financial, natural, industrially processed - which make independence particularly daunting (Nielsen, 2000). But the less-than-rosy experiences of larger decolonized states possibly also add to the reluctance observed in these small polities (Grovogui, 2012). Indeed, not all candidates have chosen the path of independence. On 25 November 2008, a majority of the people of Greenland voted in favour of enhanced home rule 'self-government' - still within formal Danish sovereignty. Denmark and Greenland alike are preparing for a future envisioned as involving climate change, intensive raw material extraction, new transportation corridors and new claims to sovereignty over the Arctic. Greenland uses this imagined future as a way of enhancing its subjectivity - not least when dealing with the EU.

In 1985, Greenland became the first territory ever to leave the EEC when it opted for a status as an 'overseas country or territory'. The EU treaty framework holds a special place for such nonsovereign, overseas islands with ties to an EU member state (Hannibal et al., 2012). Among these, Greenland is the one most consistently building up to acquiring its own sovereignty (Adler-Nissen and Gad, 2012: 238-9). The way Greenland had to follow Denmark into the EEC in 1973 whereby Greenlanders saw control over their fisheries move from distant Copenhagen to evenmore-distant Brussels - was pivotal for the Greenlandic demands for home rule, which succeeded in 1979 and made the 1985 withdrawal possible. 
This article analyses how the Greenlandic self-image as being on the path to full sovereignty - and the tensions involved - structure the triangular relationship between the EU, Greenland and Denmark. The article primarily focuses on the Greenlandic perspective - but as this is shaped by the mutual relations to Copenhagen and Brussels, the Danish and EU perspectives necessarily come into view. The Greenland-EU relationship can best be understood by exploring the development from Danish colonialism to a future independent Greenlandic state: this development involves, first, a tension between the development towards self-sustainability in terms of welfare versus the preference for deciding for oneself. More specifically, it involves maintaining the cash flow from Brussels while returning as few fishing quotas as possible and keeping sovereignty from 'going south'. Second, the development involves tension between two distinct approaches to gain recognition and subjectivity on the world scene: on the one hand, protecting certain practices deemed central to indigenous Inuit culture - specifically, the killing and consumption of certain wild animals - even if Danish sovereignty must be utilized as a lever to achieve this end. On the other hand, posing as a polity in charge of its own business - despite the current, formal Danish sovereignty.

The proceeding section tells a story about how Greenland's experience with sovereignty as a part of the Danish empire has shaped national identity discourse - and a history of how the Greenlandic relationship to the EU has been intimately interwoven with the Greenlandic developments towards independence. Then, a section demonstrates how Denmark is 'photo-shopped out of the picture' when the - still less-than-sovereign - government of Greenland rhetorically portrays the relations to the EU of this Greenland working to leave non-sovereignty behind. By removing Denmark from the picture, the Greenlandic government engages in a strategy to build up expectations at home and abroad of a Greenland taking care of its own business - a sovereign Greenland. A further section zooms in on the practical games necessary to beef up the bureaucratic muscle of a fragile 
microstate. Greenland's approach has - pragmatically - been to utilize the Danish EU membership as a platform for its relations with the EU. Nevertheless, the tension between development towards self-sustainability and self-government must be handled. And so does the tension between indigeneity and statehood. The practical handling of the relationship to the EU has relied on an intricate relationship with Denmark. During the first decade of the new millennium, however, the practical handling of the relationship is substantially 'Greenlandicized'.

The article concludes that the visions of sovereign equality might create greater expectations than Greenland will immediately be able to live up to - at home and in the EU. On the other hand, as the realization of the expectations seems to be conditioned on the expectations being built up, Greenlandic nationalism might ultimately be able to drag itself up by its own bootstraps. The representation of the Greenland-EU relationship as one of sovereign equality - present and future might just be able to stimulate the resources necessary to make the dream come true.

\section{Greenland's experience with sovereignty}

One can easily tell a history of Greenlandic national identity - including a concept of sovereignty as something worth striving for - as a product of the bilateral relationship with Denmark. This is what this section begins with. The second task for this section, however, is to re-tell the story with a focus on how Danish policies towards Greenland have been structured by concerns about protecting its sovereignty in relation to other states - and how Danish sovereignty games involving others have, somewhat paradoxically, empowered Greenland on its road to independence; lately not least in relation to the EU.

\section{A postimperial inconvenience to national identities}

When Norwegian vicar Hans Egede embarked for Greenland in 1721, his mission on behalf of the Danish king was to re-christen the small group of Norse who had colonized parts of Southern 
Greenland centuries earlier and take up trade: the Lutheran reformation had never reached the Norse, with whom the metropole had lost contact (Gad, 1973: 14). Instead of long-lost brethren, however, the missionary found Inuit who had immigrated down the coast from the North. The Danes took it upon themselves to baptize the heathens (Gad, 1973: 28-32). As the empire was meant to finance itself (Gad, 1973: 32), The Royal Greenlandic Trade Company was established (Gad, 1973: 374-95; Marquardt, 2006: 156). Over the centuries, the concerns of mission and trade clashed and conformed to form the pattern of settlements: the trade initially supported a dispersed, nomadic population to harvest the sea for tradables (Gad, 1973: 345-6), while parts of the mission wanted to assemble people to hear the gospel (Gad, 1973: 323, 346). Later, when the demand for skin, blubber and tooth declined, the trade saw the merits of concentrating the population to develop a fishing industry (Friis, 1999: 176-7; Sørensen, 2006: 38).

From the beginning of colonization, identification was straightforward: the Danes made the decisions (naalagat), conducted trade, did the teaching and lived in wooden or stone houses, whereas the Greenlanders were decided over, did the hunting and lived in tents or turf huts (Seiding and Toft, 2011: 273-6). For a long time, Denmark limited access for other Europeans to protect Inuit culture - not so much for the Greenlanders as to secure the supply of tradables provided by the traditional hunters (Gad, 1973: 345; Thomsen, 1996: 266). Nevertheless, a group of 'hybrids' emerged as the result of extra-marital activities and interracial marriages. This hybridity made questions of identity acute (Seiding and Toft, 2011): a boy with a Danish father had nobody to teach him hunting - but he could take up a 'Danish' job in trade (Gad, 1973: 210, 358) or as a catechist in one of the settlements along the coast (Gad, 1973: 353). In the same period, German romantic nationalism - in a specifically Danish version developed by Lutheran theologian N.F.S. Grundtvig - came to Greenland: the true potential of the nation - of any nation - demanded the enlightenment of the common man in his own language (Wilhjelm, 1997: 29). As enlightenment came from 
Denmark, however, interlocutors capable of both Danish and Greenlandic were necessary. The hybrid, hence, also found a place in the newly established teacher's college (Wilhjelm, 1997: 32, 40, 116). An independent, Greenlandic elite was established (Thuesen, 1988: 63), an elite that aspired for equality with the Danes. But even as formal, legal equality was established with the incorporation of Greenland in Denmark in 1953 (and along with incorporation: priority to Danish language at all levels), the everyday experience was still one of a clear ethnic hierarchy (Larsen, 1992b: 387; Thomsen, 1996: 271-2). The result was Greenlandic nationalism (Langgård, 2002: 79) - a nationalism which was at the same time formulated against Denmark and formed with a picture of the ideal nation state which mirrors the 'perfect' coincidence of state, nation, culture and religion which (after a series of lost wars) is Denmark's self-image.

So when Greenland identifies itself today - i.e. when people living in Greenland talk about what Greenland is and should be - diverse elements are articulated: on the one hand, Greenlandic identity has to do with cultural roots. The Greenlandic language is pivotal. So is a close relationship to nature and a traditional material culture developed for survival in the high north. A series of practices involving the killing and consumption of wild animals must therefore be protected, practiced along the coast (cf. Neumann, 2002: 110-5) and promoted abroad. ${ }^{\mathrm{i}}$

On the other hand, the political debates make clear that modern phenomena such as democracy and welfare are equally indispensable elements in what Greenland is and ought to be. As is the nationstate: no one imagines a Greenland which is not a democratic welfare state (Gad, 2005: 208). In Greenlandic identity discourse, the national principle is what ties aboriginality and modernity together: Greenland ought to be an independent state to allow Greenlandic culture to flourish within a welfare society. Some deem this impossible - some deem it a perspective far removed to the horizon - yet others would declare independence soon. So in terms of Greenlandic discourse, the present situation is not as it ought to be: Greenland is not an independent nation state. The current 
Greenlandic identity is transitional - Greenland sees itself on the way from imperial submission to future independence. In that sense, becoming independent is part of Greenlandic identity (Gad, 2005, 2009a). And in that sense, most Greenlandic domestic politics are almost by definition postimperial sovereignty games: Linguistic games allowed by the concept of sovereignty, played while leaving empire behind. These domestic games serve to 'hierarchicize' three priorities: legal self-government, economic self-sufficiency and aboriginal cultural identity. Greenland needs to be allowed to govern itself and Greenland needs to be able to sustain itself - all the while Greenland needs to preserve symbolic elements of Inuit culture as an anchor for its identity.

Seen from Denmark, the relation to Greenland is also an inconvenience to national identity discourse. Denmark and the Danes are wont to see themselves as a cultural nation which built a state to nest the unfolding of its inner qualities (cf. Østergaard, 1992: 34-5, 50; Hansen, 2002: 51-2, 60-1, 69, 80-5; Gad, 2010: 250). In Denmark-the-nation-state, there is (ideally) no room for cultural plurality (Gad, 2010: ch. 6-8). To have this conception of the nation state co-exist with an intimate relationship with a former colony necessitates linguistic and legal games. Particularly, Danish discourse requires the concept of 'Community of the Realm' [Rigsfallesskab] to make sense of the relation (cf. Gad, 2008, 2009b): the 'Realm' works as an extension of 'our state' necessitated by how the state is intimately tied to 'our nation'. And as Denmark sees itself as being on the side of the weak and equality (Hansen, 2002: 59; Due-Nielsen and Petersen, 2008: 523), this Realm cannot be conceived of as a hierarchical relationship (Gad, 2008, 2009b, 2010). Being colonizers is at odds with the Danish self-image, so the realm is something we 'share in common' with the Greenlanders. ${ }^{\text {ii }}$ The main element in the Community of the Realm - apart from legal submission - is an annual block grant from Denmark to Greenland. This element adds to the Danish self-image of being a force for good in the world: Denmark prides itself on being among the very best when it comes to providing development aid. In the same way, the annual grants to Greenland 
serve as proof of maternal benevolence - only in this relation, the colonial past makes conditionality impossible: while Denmark may paternalistically demand good governance in sub-Saharan Africa (Bach, 2008), interference in Greenlandic affairs is a much more sensitive issue (Gad, 2008, 2009b).

So Greenlandic and Danish self-images overlap enough to allow the continuation of the relationship. The basic way of legitimizing constitutional and economic dependency on both sides of the Atlantic Ocean is an agreement that Greenland needs help to develop towards self-sustenance and self-government (Gad, 2008, 2009b). The flip side of this is that the continuation of this narrative of the raison d'être of the community is endangered whenever it is implied that Greenland will never be capable of independence - or that Denmark has other motives than assisting Greenland on its way to this goal. To keep up appearances, both sides engage in games that are ultimately made possible - but also made necessary - by the either/or concept of sovereignty. In other words, to allow the continuation of the constitutional link, sovereignty has been articulated in creative ways on both sides of the Atlantic. The remaining part of this section demonstrates how Danish concerns with protecting its sovereignty over Greenland have framed the games played in the Greenland-Denmark relationship. Lately, some of these games have involved the EU as the third party.

\section{Denmark playing games to protect its sovereignty}

In 1749, Danish King Christian VII granted monopoly on trade with Greenland to the precursor of the Royal Greenlandic Trade Company. The context of the trade monopoly was, of course, competition. Specifically, Dutch and Basque whalers traded with the Inuit (Gad, 1973: 187 et passim; Marquardt 2006: 146-7, 153-4). Hence, Denmark engaged in what may count as a core colonial sovereignty game; employing sovereignty to protect the extraction of resources. The final 
round of the traditional version of this game was played in the early decades of the twentieth century, when Norwegian hunters foraged remote parts of east Greenland, later claimed by Norway. To bolster Danish sovereignty, a small group of Inuit was moved a few hundred kilometres up the east coast to Scoresby Sound to establish a permanent presence at Ittoqqortoormiit. Norway ultimately lost out at the International Court in the Hague in 1933 (Sørensen, 2006: 54). In a parallel move, Danish-Greenlandic explorer Knud Rasmussen personally established the Thule trade post in the far North West Greenland in 1910, i.a. with a view to pre-empt competing US and Norwegian claims to the territory (Müntzberg and Simonsen, 1996; cf. Lidegaard, 2003: 177-83).

During and after the Second World War, Denmark found itself in two different sovereignty games; a geostrategic game and the game of global decolonization. First, as Germany occupied Denmark, the Danish ambassador to Washington and Danish governors of Greenland 'upheld' Danish sovereignty over Greenland by letting the US protect the island (Lidegaard, 1999: 179-88, 334-5). This involved the construction of huge air force bases - operations which effectively annulled the Danish policy of keeping Greenland sealed to protect the Greenlanders (Sørensen, 2006: 62-95). With the connections to Copenhagen re-established in 1945, the US - after having considered buying the island - formally recognized Danish sovereignty in the 1951 Defence Agreement in return for being granted substantially free hands in utilizing Greenlandic territory for defence purposes (Lidegaard, 1999: 179-88, 334-5, 407). Essentially, then, Denmark maintained formal sovereignty over Greenland by emptying the concept of any content, at least when it comes to military affairs. At the same time, the decolonization process was institutionalized in the UN. The 1953 integration of Greenland as a formally equal part of Denmark kept the UN from supervising decolonization in this case (Alfredsson, 2004). By awarding the Greenlanders a formally equal share in Danish sovereignty over their island, international authority was kept from interfering in the game on behalf of a potentially independent Greenlandic sovereignty. 
The Danish moves in these three sovereignty games - resource extraction, geostrategy and decolonization - conspired to produce one of the most contested episodes in Greenlandic colonial history. Since the establishment of the Thule trade station - later taken over by the Danish state the local Inuit (called Inughuit) had largely settled to form a town. This settlement was increasingly getting in the way of the expanding US Air Base at Thule. In the very last months before the 1953 Danish constitution would award civil rights to Greenlanders, the Danish authorities moved the population from their permanent residence to form a tent village some 100 kilometres north (Eastern High Court, 2002: 63). In these earlier sovereignty games, Denmark combined two basic strategies: Sovereignty was asserted vis-à-vis the Greenlanders by forcefully producing the physical realities deemed expedient. Sovereignty was legitimized vis-à-vis third parties by paternalistically acting on behalf of the unspoiled native. Today, both strategies are difficult to pursue for reasons pertaining both to the past and to the future.

First, the increasing recognition of past colonial wrongdoings has delegitimized the paternalist pretensions of colonialism globally. In Greenland, the results of the two population transfers mentioned above are constant reminders of the colonial sovereignty games that formed them. The tiny towns of Ittoqqortoormiit in East Greenland and Qaanaaq at Thule are currently among the most fragile communities in Greenland. They are among the most impoverished communities in the country and suffer from a wide range of deep social problems. ${ }^{\text {iii }}$ As part of the 2009 transfer to selfgovernment, Denmark formally acknowledged that Greenland has the right to secede should it wish to do so. And as the following will show in relation to the EU, Denmark is only able to secure sovereignty over Greenland by placing the self-same sovereignty not just in but at the service of Greenland. This is a delicate task, likely destined to fail in the long run, as it does not merely hinge on securing the compatibility of Greenlandic and Danish national identity discourses, it also hinges on which future is imagined. 
Hence, the crucial importance of the second reason why the past Danish strategies are impossible to pursue: a widespread vision of the Arctic future awards Greenland better access to alternatives to engaging exclusively with Denmark. A new sovereignty game is currently taking shape in an Arctic that many observers imagine will open up to new players as the ice melts. On one dimension, this is a traditional horizontal sovereignty game between the five Arctic states (Russia, Canada, the US, Norway and Denmark), each seeking to secure the largest share of the Arctic Ocean by submitting geological evidence of continental continuity in accordance with the UN Convention on the Law of the Seas (Strandsbjerg, 2011) - and with massive corporations ready to step in to extract resources (Refsnes, 2011). On another dimension, the either/or concept of sovereignty implied in the claims of the 'Arctic 5' is challenged both by indigenous peoples submitting claims for sovereignty, which structures space differently (Shadian, 2010; Gerhardt, 2011), and by environmentalists and nonArtic states proposing further international regulation to protect the environment or allocate resources differently. ${ }^{\text {iv }}$

In sum, in the course of the twentieth century, Denmark has engaged in games to protect its sovereignty over Greenland by employing practical strategies at the expense of Greenlandic individuals and groups - all the while rhetorical strategies were employed to persuade both Greenlanders and outsiders that Denmark exercised its sovereignty to benefit and protect the Greenlanders. Relocating groups of Greenlanders served to secure Danish sovereignty; first under international law in the Hague; second by allowing superpower utilization of the territory formally secured. Historical shifts in which sovereignty games are deemed legitimate at the global level, however, have made the continuation of such strategies self-defeating: while constitutional incorporation in 1953 initially served to defer self-government by dodging the global decolonization process, the wrongs committed under and to protect colonial sovereignty nevertheless delegitimized Danish sovereignty over Greenland in a decolonized context to the point where formal Greenlandic 
sovereignty is merely a matter of Greenland formally claiming it. Meanwhile, the substantial resources deemed necessary for Greenlandic sovereignty to be more than an empty shell appear to be materializing as the Arctic ice continues to melt - not just because the climate becomes less prohibitive for the extraction of Greenlandic minerals but also because the accompanying interest from new business partners and rising powers conveys the impression that Greenland has alternatives to Denmark.

\section{Greenland playing games to enhance subjectivity}

Greenland utilizes this new game - opened up by improved prospects for being able to harvest resources in the Arctic - to empower itself in its relations to the EU. This relationship is itself the result of an intersection of different sovereignty games: from its very conception, the European treaties included special provisions for those of the member state's colonies that did not seek independent sovereignty, opting instead to remain 'overseas countries and territories' (OCTs) (Gad and Adler-Nissen, 2012). When Denmark became engaged in the late sovereignty games of European integration (cf. the introduction to this issue), these provisions came in handy.

Until recently, Greenland was the only EC territory to ever cede membership status. ${ }^{\mathrm{v}}$ When Denmark became a member of the EC in 1973, Greenland also had to join despite a $70 \%$ majority against doing so (Petersen, 2006). Since the 1953 constitution, Greenland had been considered a part of Denmark - and unlike the Faroe Islands it did not have a home rule arrangement to provide for a separate path: the Faroes stayed out of the EU along with other Nordic fisheries nations (Iceland and Norway). The 1972 referendum campaign in Greenland was also focused on fisheries. The decisive argument boiled down to a claim that 'Now, Copenhagen decides who may catch our fish - in the future, the decisions will be taken even further away; in Brussels' (Skydsbjerg, 1999: 25). To allow for more - not less - subjectivity, new legal arrangements were called for: The urge 
to leave the EC was so strong that it was decisive in the struggle for home rule (cf. Lauritzen, 1997[1973]: 15-21).

Greenlandic home rule was established in 1979 and Greenland was moved to the OCT arrangement after complex negotiations on the unprecedented request to leave the EC. ${ }^{\text {vi }}$ The package deal negotiated included a fisheries agreement which traded EC access to Greenlandic waters for tax free access for Greenlandic fisheries products to the European Single Market and a lump sum which matched the previous transfers to Greenland from the social and structural funds (Skydsbjerg, 1999: 26). ${ }^{\text {vii }}$

Copenhagen had left its fisheries policy to Brussels as part of the European sovereignty game in which sovereignty is distributed not just territorially but also - and increasingly - functionally (cf. the introduction to this special issue). The Greenlanders had already 'taken home' from Copenhagen $^{\text {viii }}$ the fisheries policy as a home rule issue. The bottom line is that since leaving the EU in 1985, Nuuk has had de facto sovereignty over fisheries; a sovereignty used to trade fish for cash. But the cash stream soon appeared fragile and sovereignty did not in itself secure cultural identity.

First, some of the fish sold were 'paper fish', which the Commission had originally invented so that they could be redistributed in the on-going haggling over quotas. ${ }^{\mathrm{ix}}$ During the 1990s, the EU realized that the money spent on Greenlandic paper fish could be spent better on real fish along the coastlines of African states. In 2006, however, a new special partnership agreement foreseeing increased cooperation in a number of areas presumably of interest to the EU - including minerals, transportation and climate research - legitimized a budget line allowing the funding of Greenlandic sustainable development of human resources through education, even though Greenland is more affluent than the EU average, let alone the countries covered by the EU development programmes. 
Second and less immediately reparable, formal sovereignty did not immediately secure cultural identity: On the one hand, Greenlandic identity discourse involves development towards selfsufficiency under the conditions of a globalizing world economy. This has implied a centralization of deep sea fishing on very few boats, controlled by very few people. On the other hand, Greenlandic identity discourse involves care for a traditional culture - which is implied to require a distribution of the population in small settlements along the coastline, depending for their livelihood on small-scale fishing and hunting. On top of the concentration of the fisheries, Western animal rights groups have attacked a series of indigenous hunting practices (whaling, sealing and trapping) which carry weight as they pertain to icons of Inuit culture. In a series of these cases, Greenland has tried to influence the EU to either change EU regulations threatening Greenlandic interests or to gain European support in preventing international regulations or challenging, i.a., US regulations. In these cases, Greenland has variously attempted to limit and influence Danish and EU sovereignty and attempted to employ Danish and EU sovereignty further abroad.

As the then Prime Minister of Greenland explained, in contrast to the Faroes, Greenland has consciously chosen to 'use the Danish platform' when dealing with the EU. ${ }^{\mathrm{x}}$ The choice of metaphor is interesting: a platform is something you stand on to reach things you would otherwise not be able to reach. In terms of the metaphor, then, the Greenlanders are the active part doing their own thing, while the Danish platform is passive. As seen in the next section, this is very much in line with how Greenland likes to present itself in Brussels and how Greenlandic politicians like to present affairs at home. As the proceeding section lays out, things are slightly more complicated in the practical games played in Brussels. 


\section{Greenlandic visions of sovereign equality}

As demonstrated above, the fear of letting sovereignty over fisheries - as well as power over the future development of Greenland in general - go south to Brussels was decisive when Greenland voted against the EU in referenda in 1972 and 1982. The self-image of Greenland as a nation on its way to self-government made EU sovereignty over fisheries unbearable. Among the proponents of EU membership, however, the development of Greenland towards economic self-sufficiency was at the top of the agenda - more specifically; the contributions of the EU to the Greenlandic budget and to development projects in Greenland.

The last general debate in the Greenlandic parliament on the EU took place in $2007 .{ }^{\mathrm{xi}}$ Also this debate played out around these two concerns: self-government and self-sufficiency - even as proponents of EU membership limited their demands to asking for an investigation into alternatives to the present arrangements, ${ }^{\mathrm{xii}}$ which - as laid out above - amounts to OCT status supplemented by fishery and partnership agreements.

As for the pecuniary question, the membership proponents claimed that membership of the EU ... will be able to accelerate the process towards an independent Greenland ... It will be possible to introduce independence without a drop in the standard of living or the level of service, as Greenland will be able to obtain more funds from the EU than is the case today. ${ }^{\text {xiii }}$

The minister rebuffs by reminding of the relative affluence of Greenland:

[C]oncerning structural funds and social funds [it ... sounds] like the purse is just open ... this is hardly correct. First, one has to apply ... then one gets a share depending on the needs of the member states ... Greenland [would be] number 10 or 
11 [if inserted into the list of 27 EU member states] when it comes to the GDP pr. capita ... so [we] should ... not imagine that the purse is just open. ${ }^{\text {xiv }}$

When it comes to the question of influence, the proponents of membership seek recourse in a trope well-known from Danish debates on EU membership (especially when the Danish opt outs from the Euro, Justice and Home Affairs, etc., are discussed):

[W]e will - so to speak - have a seat at the table. This will increase our possibilities for exercising influence on issues important to our country ... The influence of the EU on legislation and regulation in Denmark as well as in Greenland is already - whether we want to admit it or not - rather great, and therefore ... we might as well try to be part of influencing the decision-making process as much as possible. This we may only do via membership. ${ }^{\mathrm{xv}}$

In this case, the minister's reply begins by reminding on whose lap Greenland will have to sit to be at the table:

In the present constitutional situation, EU membership will only be possible as a part of Denmark ... Greenland will not directly and automatically be guaranteed participation in meetings where questions of interest for Greenland are dealt with. In every single case, participation will have to follow an agreement with the Danish government and have to take place as part of a Danish delegation. ${ }^{\text {xvi }}$

Interestingly, this future-to-be-avoided (because it allows a disturbingly prominent role to Denmark) is contrasted to a present in which Denmark does not stand between Greenland and the EU:

[T] he prescriptions for mutual dialogue in existing agreements [i.e. OCT, fisheries and partnership] are better at securing Greenlandic interests at direct meetings between the 
Commission and Greenland ... [Now, w]e can have a direct dialogue with the EU, and if we become members, then we will have to be dragged around by Denmark inside the EU. ${ }^{\mathrm{xvii}}$

So when explaining the benefits of the present relationship with the EU to a domestic audience, Denmark tends to disappear: Greenland and the EU have a direct - and in that sense equal relationship. ${ }^{\text {xiii }}$ In this way, a Greenland of the future is presented to its own people: a Greenland which has broken with the colonial dependency of the past and is already taking care of its own international relations. A Greenland which, for all practical purposes, enjoys sovereign equality in relation to the EU. By articulating the concept of sovereignty creatively, the government of Greenland may present a Greenland to its own citizens which is more attractive in the terms of Greenlandic identity discourse than the one formal legal analysis would suggest.

When communicating with the EU, Greenland also envisions sovereign equality by photo-shopping Denmark out of the picture. First, when writing about the future of the relationship at the most abstract level, Greenland avails itself of the discourse about a future Arctic bonanza to describe itself as commanding unique resources, which it may choose to offer either to the EU or another party, depending on how forthcoming the partners show themselves to be in relation to Greenland's need for both cash flow and recognition of the symbolically important cultural practices involving the killing of wild animals. Most strikingly, Denmark is not even mentioned in the descriptions of this future. Consequently, Greenland presents itself as an independent subject capable of engaging in a traditional zero-sum sovereignty game with the EU. ${ }^{\mathrm{xix}}$ Second, when handling the relationship to the EU in day-to-day diplomacy, Greenlandic officials have since the first posting in 1992 of a Greenlandic representative at the Danish Representation in Brussels prioritized an independent visual presence. Today, the Greenland Representation has four full-time employees - and visitors no longer have to pass Danish flags to talk to them; a separate entrance flanked by Greenlandic 
insignia has been established. Parallel games are played in official meetings and texts relating Greenland to the EU - games which need not only acceptance from Denmark but also acceptance from the EU. ${ }^{\mathrm{xx}}$ Independent visibility seems to have paid off. Greenlandic officials stress that it is

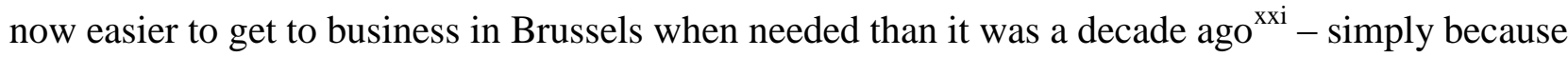
there is a higher degree of awareness that Greenland exists. ${ }^{\text {xxii }}$

Both in Brussels and at home, the government of Greenland lets Denmark out of the picture when portraying the relationship to the EU. Sovereignty - formally residing in Copenhagen - is, hence, creatively articulated with a view to enhancing Greenlandic subjectivity. Greenland has not claimed sovereignty - but it mimes sovereignty and may thereby achieve something else (Gad and AdlerNissen, 2012): legitimacy from its own citizens, attention from the EU, and potentially commitment to further engagement from both domestic and foreign audiences.

\section{Handling the relation in diplomatic practice pxii $^{\text {in }}$}

As mentioned earlier, a then Prime Minister of Greenland described Denmark in terms of a mere 'platform' for Greenland's relationship to the EU - and when the government of Greenland describes its relationship to the EU in both their parliament and in Brussels, Denmark is routinely photo-shopped out of the picture. The practical games played in Brussels seem, however, to imply a distribution of agency which is more complex than the platform metaphor and the photo-shopping would allow.

Most of those interviewed find that persons matter in a small-scale diplomatic corps. ${ }^{\text {xiv }}$ From this point of view, it might prove significant that a generational change has taken place in how Greenland-EU relations are handled. Since the branching off of Greenland-EU relations from Danish-EU relations in the mid-1980s, they have basically been handled by the same trio: first, Greenland's representative in Brussels; second, the head of the Greenlandic representation in 
Copenhagen, who doubles as the chief negotiator of Greenland's international fisheries agreements. Both were Danes with personal ties to Greenland, who began their carriers in the Danish colonial administration but were 'taken home' by the home rule government after it was established in 1979 . The third member of the trio was the Danish Ministry of Foreign Affairs' old hand on Greenland's EU relations. The fact that the members of the trio retired between 2007 and 2011 not only brought an end to a continuity which was rather unique for both the Greenlandic bureaucracy and for the Danish MFA; their retirement also allowed a 'Greenlandization' and possibly signals a Danish detachment.

A basic benefit of continuity was, of course, first-hand experience with previous rounds of negotiations with the EU. The continuity of the Greenland-EU portfolio in the Danish MFA also secured that at least one person in Denmark might be granting qualified attention to EU issues that might be relevant for Greenland in a way which does not conform to regular Danish priorities. ${ }^{\mathrm{xxv}}$ This concern was why the Government of Greenland requested the continuity. ${ }^{\text {xxvi }}$ The flipside of this continuity, however, was that Greenlanders ultimately worried that the Danish MFA might find that loyalty shifted from Copenhagen to Nuuk, endangering the point of the whole setup. ${ }^{\text {xxvii }}$ In more subtle ways, the continuity of portfolios - and the continuity of personal experience and contacts across the fine line between Danish and Greenlandic bureaucracy - provided advantages to the home rule government in negotiations. When comparing his conditions to those of his Icelandic colleagues, one Greenlandic official notes that inside knowledge of the EU's internal coordination procedures has made a significant difference - not only in terms of the elegance with which the negotiations could be conducted but also in terms of the results. The inside knowledge came both from personal experience from earlier assignments within what was then the Danish Ministry for Greenland - but also from relating to sympathetic Danish colleagues sitting on the European side of the table representing Denmark as a member state in the internal EU coordination. ${ }^{\text {xxviii }}$ 
Moreover, continuity allowed the trio to develop a distinct distribution of roles. Of particular interest are the postcolonial blame games occasionally played by one Greenlandic official in particular. They involved literally kicking doors open to get access and slamming them shut behind him when leaving meetings in anger. ${ }^{\text {xxix }}$ These games also involved 'publically' criticizing the Danish official present at a meeting with European counterparts for acting in a 'colonialist' manner. $^{\mathrm{xxx}}$

Overall, it is difficult not to find the outcome of the games successful when considering the core priorities of Greenland: to keep both the cash flow from Brussels and self-government in fisheries intact. When asked to explain the success, however, interviewees place the decisive agency differently: while some insist that the result came about because the assets which Greenland commands (fish) were simply necessary for the EU to acquire, ${ }^{\mathrm{xxi}}$ others ascribe the success to the elaborate and broad-spectre preparatory efforts coordinated between Greenland and Denmark, including the combination of ministerial tourism, writing the self-interest of the EU and documenting Greenland's needs and potentials in detail. ${ }^{\text {xxxii }}$ Others yet insist that what made the EU agree was a high-level conversation in which the President of the European Commission asked the Danish Prime Minister whether 'the member state really meant' the demands put forward by the Greenlanders. ${ }^{\text {xxxiii }}$ More interesting than the question of which story might be the best approximation to reality is to note how the three narratives match three different political stances to the present and future of the Community of the Realm hinted at above: An unnecessary straitjacket for a Greenland ready to secede; a handy working relationship until Greenland is ready; and the framework for maternalistic Danish benevolence necessary to endure, as Greenland is too small to ever handle independence.

In the cases where Inuit traditions of killing wild animals have been under attack, there is no doubt that Danish support - especially in the Council of Ministers - has been central to any success with 
influencing the EU. But Danish support has been neither unlimited nor automatic, as the Danish position is to be formulated as a compromise between, on the one hand, North Atlantic priorities and, on the other, Danish public opinion and consistency with the more conservationist position Denmark advocates in comparative cases outside the Community of the Realm. ${ }^{\text {xxiv }}$ A recent case provides a vivid example of the importance attached to the issue - and of the difficulties it entails: in 2009, the EU prepared a ban on the import of sealskin. In a letter to, i.a., the presidents of the European Commission and the European Parliament, the speaker of the Greenlandic parliament warned that Europe was repeating the colonial policies pursued in South America 400 years ago and thereby committing 'cultural genocide' (Motzfeldt in KNR, 2009; cf. ICC, 2009). Behind the fears of the collapsing market was the threat to cultural practices described as essential to Inuit identity (Fægteborg, 1990; Gad, 2005: ch.2) posed by Western standards of 'humane' treatment of animals. ${ }^{\mathrm{xxx}}$ Concerted and persistent Danish-Greenlandic action secured that the recent ban on the import of sealskin exempts skin produced by traditional hunters. This exemption did not, however, ameliorate the fears of the government of Greenland that sealskin would be impossible to sell in Europe for all practical purposes (GoG, 2009). The Greenlandic government considered at one point asking Denmark to act on its behalf in the WTO to challenge the ban on the import of sealskin introduced in the EU (including Denmark). ${ }^{\text {xxvi }}$ One Greenlandic official mentioned this case as one in which the constitutional link to Denmark - and Denmark's lack of good will on a specific point has been a barrier to pursuing Greenlandic interests: under conditions of formal sovereignty, Greenland would have been free to follow Canada on this. ${ }^{\text {xxxvii }}$

The generational change in the handling of Greenland's EU relations has meant that they are now entirely in the hands of bureaucrats and diplomats without personal memory of Denmark's handling of pre-Home Rule Greenland as part of the EC. This has meant a 'Greenlandization' of the handling which is described as 'only natural'. xxxviii The Greenlandic representatives in Brussels and 
Copenhagen along with the chief fisheries negotiator (now based in Nuuk) and the Greenland-EU desk officer in the Danish MFA are now all Greenlanders - products of Danish and international higher education but with the Home Rule administration as their central job experience. Apart from this Greenlandization, however, the generational change also seems to involve a sense of Danish detachment: the Greenland-EU file in the MFA has been merged with the general Greenland file and allocated to a Greenlander temporally employed rather than to a career diplomat. Meanwhile a separate position as 'Arctic Ambassador' has been formed and filled with MFA seniors with no particular Greenlandic experience. The Greenland file at the Danish permanent representation in Brussels is now a side task for younger diplomats rotating in and out of town every few years. ${ }^{\text {xxix }}$ The bulk of the workload and the initiative in handling the day-to-day business of Greenland vis-àvis the EU would gradually seem to have shifted from the Danish to the Greenlandic side. ${ }^{\mathrm{xl}}$ Asked about the possible consequences of the generational change for the - more heavy-duty negotiations of Greenland's partnership and fisheries agreements with the EU, one central Greenlandic official finds that losing the memory of alternatives left behind 'may, after all, be both bad and good'. xli

\section{Conclusion: the place of Denmark - already in the past}

Greenland's relationship with the EU combines two elements: First, Greenland uses the Danish membership as a 'platform' from which to handle its EU relations. Second, Greenland sports a national identity narrative which projects a sovereign Greenlandic nation state imagined by simultaneously mirroring and liberating itself from the Danish nation state. The combination of an urge to realize a sovereign nation state which is distinctively post-Danish in its insistence on the coincidence of state and nation with a practical dependence on Danish sovereign diplomacy has necessitated that games are played with present Danish sovereignty in both the practical handling 
and the discursive presentation of the relations to the EU. Particularly, in a number of instances, Denmark is photo-shopped out of the picture in both rhetoric and practice, at home and abroad: Greenland speaks and acts as if the relationship to Denmark was already a thing of the past. This arrangement, notably, is also convenient for Denmark: by 'allowing' Greenland to act independently, Denmark may escape the embarrassment of the 'colonialist' label. In a number of instances, however, one might foresee the breakdown of some of the games if they come to interfere with each other in specific ways:

First, while the former colonizer is photo-shopped out of the picture in certain instances, the practical handling of the relationship relies on Denmark in a way which goes beyond what may meaningfully be described as a platform. Perhaps the coming of age of a new generation of Greenlandic civil servants, working under a political leadership more determinedly committed to Greenlandic independence, will find an increased urge - or need - to make Denmark even less active.

Second, in the rhetorical construction of narratives of the relationship, politicians may find themselves in a crossfire: describing the present relationship to the EU as one of sovereign equality may score points at home, but overplaying the present independence may be risky when talking to a Commission anxious not to interfere in the constitutional relations between its member states and their overseas countries and territories. ${ }^{\text {xlii }}$ Describing the future relationship as one of sovereign equality may score points both at home and in Brussels - but it makes Greenland dependent; first, on a geopolitical discourse which may not turn out to be beneficial to a microstate; and second, on a discourse on future resources and opportunities in the Arctic which may or may not materialize. If not overplayed, however, the two narratives may actually sum up to a credible strategy, allowing Greenland to drag itself up by its bootstraps: if - by telling the Greenlanders that they are taking care of their own relations with the EU themselves in virtual sovereign equality - they provoke the 
very civic engagement and energy needed for Greenland to actually fend for itself, then sovereign equality is a good step closer. If - by telling the EU that Greenlandic resources are necessary and valuable - they stimulate the investments necessary to indeed realize the potential resources; then formal sovereignty is a good step closer; provided that the resources - human and natural - show up when envisioned into being. A sovereignty which will be distinctively post-Danish in how it is modelled on a Danish ideal which stipulates that sovereignty ultimately belongs to a culturally homogenous people.

The way the Greenlandic government has engaged in sovereignty games in its relations with the EU shows that a non-sovereign polity can enhance its own subjectivity in relation to third parties. Greenland's strategy has a double effect: it has made the acquisition of full formal sovereignty more plausible while at the same time widening the room to manoeuvre within (post-)imperial sovereignty. Notably, this has been achieved by refraining from a general confrontation (rhetorical or otherwise) with Denmark. Rather, confrontations with the colonial overlords have been carefully calculated and occasionally staged to achieve maximum concessions from the EU. These calculations and theatrics have, of course, relied on a particular constellation of past and future: the undeniable history of imperial subjugation combined with the enticing projection of an Arctic bonanza ahead. Hence, Greenland may credibly present itself as both a victim of past Danish sovereignty games and an important player in future Arctic sovereignty games in ways which are not open to other micropolities in Norden or overseas.

\section{References}

Adler-Nissen R and Gad UP (2012) Conclusion: when European and Postcolonial Studies meet. In: Adler-Nissen R and Gad UP (eds) European Integration and Postcolonial Sovereignty Games: The EU Overseas Countries and Territories. London: Routledge, pp.235-245.

Alfredsson G (2004) Greenland under Chapter XI of the United Nations Charter: a continuing international law dispute. In: Skaale S (ed) The Right To National Self-Determination: The Faroe Islands and Greenland. Leiden: Martin Nijhof, pp.49-94. 
Bach CF (2008) Foregangslandet under forandring. In: Due-Nielsen C, Feldbæk O and Petersen N (eds) Idealer og realiteter. Dansk Udviklingsbistands Historie 1945-2005. Copenhagen: Gyldendal, pp.390-515.

Baldacchino G (2012) The micropolity sovereignty experience: decolonizing, but not disengaging. In: Adler-Nissen R and Gad UP (eds) European Integration and Postcolonial Sovereignty Games: The EU Overseas Countries and Territories. London: Routledge, p.53-76.

Bendtsen M (2012) Grundbog om at flytte til Grønland og arbejde i det grønlandske sundhedsvaesen. Nuuk: Det Grønlandske Sundhedsvæsen.

Bjerregaard P and Dahl-Petersen IK (2011) Sundhedsundersøgelsen i Avanersuaq 2010. SIF's Grønlandsskrifter 23. Copenhagen: National Institute of Public Health, University of Southern Denmark.

Due-Nielsen C and Petersen N (2008) Nogle hovedtræk i dansk udenrigspolitik 1945-2005. In: Due-Nielsen C, Feldbæk O and Petersen N (eds) Idealer og realiteter. Dansk Udviklingsbistands Historie 1945-2005. Copenhagen: Gyldendal, pp.516-534.

Eastern High Court (2002[1999]) Reasons and ruling in Hingitaq 53 vs. Denmark, extract from section 7. In: Lynge A (2002) The Right to Return: Fifty Years of Struggle by Relocated Inughuit in Greenland. Nuuk: Atuagkat, appendix.

Friis P (1999) Det grønlandske fiskeri. In: Lorentzen J, Jensen EL and Gulløv HC (eds) Inuit, kultur og samfund - en grundbog i eskimologi. Aarhus: Systime, pp.173-188.

Fægteborg M (1990) Den menneskelige dimension. Tidsskriftet Grønland 38(8): 248-254.

Gad F (1973) The History of Greenland, Vol. II: 1700-1782. London: C. Hurst \& Co.

Gad UP (2005) Dansksprogede grønlanderes plads $i$ et Grønland under grønlandisering og modernisering. Copenhagen: Eskimologis Skrifter nr. 19.

Gad UP (2008) Når mor/barn-relationen bliver teenager: Kompatible rigsfællesskabsbilleder som (dis)integrationsteori. Politica 40(2): 111-133.

Gad UP (2009a) Post-colonial identity in Greenland?. Journal of Language and Politics 8(1): 136-158.

Gad UP (2009b) Un avenir postcolonial groenlando-danois? Trois scénarios pour la dissolution de la Communauté du royaume - et trois autres pour son maintien et sa modification. Nordiques 18: 69-87.

Gad UP (2010) (How) can They become like Us? Danish identity politics and the conflicts of 'Muslim relations'. PhD dissertation, University of Copenhagen.

Gad UP (2012) Greenland projecting sovereignty: Denmark protecting sovereignty away. In: Adler-Nissen R and Gad UP (eds) European Integration and Postcolonial Sovereignty Games: The EU Overseas Countries and Territories. London: Routledge, pp.217-234.

Gad UP and Adler-Nissen R (2012) Introduction: postcolonial sovereignty games in the margins of Europe. In: AdlerNissen R and Gad UP (eds) European Integration and Postcolonial Sovereignty Games: The EU Overseas Countries and Territories. London: Routledge, pp.1-24.

Gad UP, Hannibal I, Holst K and Adler-Nissen R (2011) EUs oversøiske lande og territorier: postkoloniale suverænitetsspil og Grønlands arktiske muligheder. Politik special issue on the Arctic 14(1): 15-24. 
Gerhardt H (2011) The Inuit and sovereignty: the case of the Inuit Circumpolar Conference and Greenland. Politik 14(1): 6-14.

Government of Greenland (2009) Ban on sealskin products is catastrophic for Greenland. Press release, Minister for Fishing, Hunting and Agriculture. Available at:

http://uk.nanoq.gl/Emner/News/News_from_Government/2009/05/sealskin.aspx (accessed 6 April 2011).

Grovogui SN (2012) Postcolonial sovereignty: experimentation with statehood and self-determination. In: Adler-Nissen $\mathrm{R}$ and Gad UP (eds) European Integration and Postcolonial Sovereignty Games: The EU Overseas Countries and Territories. London: Routledge, pp.25-38.

Hannibal I, Holst K, Gad UP and Adler-Nissen R (2012) European Union: Facilitating the OCTs in Brussels. In: AdlerNissen R and Gad UP (eds) European Integration and Postcolonial Sovereignty Games: The EU Overseas Countries and Territories. London: Routledge, pp.77-95.

Hannibal I and Holst K (2010) Europas permanente paradoks? EUs oversøiske lande og territoriers suveranitetsspil $i$ Brussels. Unpublished MA Thesis, University of Copenhagen, Denmark.

Hansen L (2002) Sustaining sovereignty: the Danish approach to Europe. In: Hansen L and Wæver O (eds) European Integration and National Identity: The Challenge of the Nordic States. London: Routledge, pp.50-87.

Harhoff F (2003) Rigsfallesskabet. Aarhus: Klim.

Høydal H (2000) Myten om rigsfallesskabet - vejen til en selvstandig farøsk stat. Copenhagen: Lindhardt og Ringhof.

ICC (2009) Response from the Inuit Circumpolar Council. Available at:

http://www.inuit.org/index.php?id=293\&contUid=0; undated (accessed 6 April 2011).

KNR (2009) Jonathan Motzfeldt til EU: Skam dig, Europa. Available at:

http://knr.gl/index.php?id=297\&tx_ttnews[tt_news]=43357\&tx_ttnews[backPid]=844\&cHash=3d539d2ee6\&cHash=31 8c8bf3c5 (accessed 1 May 2010).

Kristensen KS (2004) Greenland, Denmark and the Debate on Missile Defense: A Window of Opportunity for Increased Autonomy (DIIS Working Paper 2004/14). Copenhagen: Danish Institute for International Studies.

Langgård K (2002) Fjeld, elv og hav. Natursynet i "Tarrarsuummi tarraq/Saltstøtten". In: Janussen E et al. (eds) Grønlandsk kultur-og samfundsforskning 2000/01. Nuuk: Ilisimatusarfik/Atuagkat, pp.73-98.

Larsen FB (1992) The quiet life of a revolution: Greenlandic Home Rule 1979-1992. Études/Inuit/Studies 16(1-2): 199-226.

Lauritzen P (1997) Philip Lauritzen i Grønland. 21 års journalistic. Copenhagen: Tiderne Skifter.

Lennert KH (2006) The Danish interests in the Community with Greenland. Unpublished MA Thesis. Aalborg University. Denmark.

Lidegaard B (1999) I kongens navn. Henrik Kauffmann i dansk diplomati 1919-1958. Copenhagen: Samleren.

Lidegaard B (2003) Overleveren 1914-1945. Dansk Udenrigspolitisk Historie Vol. 4. Copenhagen: Gyldendal.

Lindroth M (2011) Paradoxes of power: indigenous peoples in the Permanent Forum. Cooperation and Conflict 46(4): $543-562$. 
Marquardt O (2006) Change and continuity in Denmark's Greenland policy 1721-1870. In: Heinzelmann E (ed) The Oldenburg Monarchy: An Underestimated Empire?. Kiel: Verlag Ludwig, pp.143-175.

Müntzberg G and Simonsen, P (1996) Knud Rasmussen og handelsstationen Thule 1910-1927. Historie/Jyske Samlinger 1996(2): 209-242.

Neumann IB (2002) This little piggy stayed at home: why Norway is not a member of the EU. In: Hansen L and Wæver $\mathrm{O}$ (eds) European Integration and National Identity: The Challenge of the Nordic States. London: Routledge, pp.88129.

Nielsen JK (2000) Kriterierne for Grønlands økonomiske bæredygtighed. Politica 32(1): 22-32.

Petersen H (2006) Grønland på verdenskortet. In: Petersen H (ed) Grønland $i$ Verdenssamfundet. Udvikling og forandring af normer og praksis. Nuuk: Atuagkat, pp.7-28.

Refsnes A (2011) Global Miljøstyring av Olje- og Gassaktiviteter i Arktis: Et institusjonalisert samarbeid eller en uforrmell dialog?. Tidsskriftet Politik 14(1): 33-42.

Seiding IH and Toft PA (2011) Koloniale identiteter. In: Høiris O and Marquardt O (eds) Fra vild til verdensborger. Grønlandsk identitet fra kolonitiden til nutidens globalitet. Aarhus: Aarhus University Press, pp.273-325.

Sermitsiaq (2009) Government considers seal trade ban appeal. Available at: http://sermitsiaq.gl/indland/article91447.ece?lang=EN, (accessed 6 April 2011).

Sermitsiaq (2010) Demokrater hilser EU-debat velkommen. Available at: http://sermitsiaq.gl/politik/article109689.ece, (accessed 6 April 2011).

Shadian J (2010) From states to polities: re-conceptualizing sovereignty through Inuit governance. European Journal of International Relations 16(3): 485-510.

Skydsbjerg H (1999) Grønland. 20 år med Hjemmestyre. Nuuk: Atuagkat.

Strandsbjerg J (2011) Geopolitik, naturlige grænser og 'kartopolitik' i Arktis. Tidsskriftet Politik 14(1): 51-60.

Strandsbjerg J, Schlæger J and Gad UP (2011) Introduktion. Tidsskriftet Politik 14(1): 3-4.

Sørensen AK (2006) Denmark-Greenland in the twentieth century. Monographs on Greenland. Man \& Society 34. Copenhagen: Museum Tusculanum.

Thomsen H (1996) Between Traditionalism and Modernity. In: Jacobsen B (ed) Cultural and Social Research in Greenland 95/96. Essays in honour of Robert Petersen. Nuuk: Ilisimatusarfik/Atuakkiorfik, pp.265-278.

Thorleifsen D (1999) Dansk kolonistyre. In: Gynther B and Møller A (eds) Kalaallit Nunaat. Gyldendals bog om Grønland. Copenhagen: Gyldendal, pp.223-232.

Thuesen S (1988) Fremad, opad. Kampen for en moderne grønlandsk identitet. Copenhagen: Rhodos.

Tobiassen S (1995) Fra danisering til grønlandisering. Forventninger og realiteter om grønlandisering. Unpublished MA Thesis. University of Greenland, Greenland.

Wilhjelm H (1997) De store opdragere. Grønlands seminarier i det 19.århundrede. Det grønlandske selskabs skrifter. Copenhagen: Det grønlandske Selskab. 


\section{Acknowledgements}

Thanks to, in particular, Rebecca Adler-Nissen, Uffe Jacobsen, Iver Neumann and an anonymous Cooperation \& Conflict reviewer for valuable comments on an earlier version of this article. Thomas Basbøl, Rune Bennike and Mikaela Engell helped with specific details.

\footnotetext{
${ }^{\mathrm{i}}$ Greenlanders play an active part in the global movement of indigenous peoples concentrating on the United Nations Permanent Forum on Indigenous Issues. This forum is an important arena for sovereignty games in which colonized peoples seek to challenge both the individual states and the system of sovereign states by appropriating and 'stretching' the language and tools of the selfsame states (Lindroth, 2011). Specifically, the Government of Greenland is represented in the UNPF as part of the Danish delegation, while the Inuit Circumpolar Conference (ICC) is part of the caucus of indigenous NGOs, even if the Greenlandic chapter of ICC is mainly funded by the Parliament of Greenland. Only in relation to the right to kill wild animals, however, does the Greenlandic government bring the language and practices of the indigenous movement to the sovereignty games played in relation to the EU. In the general relations and in relation to other specific issue areas, Greenland presents itself as a state in the making rather than as an indigenous people.

ii The Greenlandic term for 'community of the realm', naalagaaffeqatigiinneq, literaly translates into a relationship which is even more explicitly equal than the Danish version: naalagaq means the one who decides - in this case, what is done is qatigiinneq; something which is done together with someone (else) (Lennert, 2006: 1, n.2; Gad, 2008: 122). The Faroes are part of the same community - but that plays no significant role in the debates Greenland nor Denmark: The community of the realm is basically discussed as two bilateral relations (Denmark-Greenland and Denmark-Faroes). Critics insist that, in legal terms, the 'community' part of the label is void, as what the label covers are unilateral delegations from the Danish Parliament (Høydal, 2000), even if some legal scholars doubt that the delegations may be withdrawn (Harhoff, 2003).

iii The official recruitment material for the Greenlandic medical service organization says that 'Ittoqqortoormiit is not a place to flee to solve one's owns problems. Ittoqqortoormiit is a place to go to if you have energy to share' (Bendtsen (ed.) 2012: 55; trl. by the author). Concerning Qaanaaq, cf. the social and medical statistics in Bjerregaard and DahlPetersen (2011).

${ }^{\text {iv }}$ In this game, Denmark's strategy has been to promote the Arctic Council as the relevant body of governance and thereby escape the 'realist' version of sovereignty-as-either/or (determined by the raw power to protect sovereignty). The Arctic Council uniquely bolsters the traditional 'legal positivist' version of sovereignty-as-either/or (determined by the right of the member states to have sovereignty) with extra legitimacy obtained from granting a special status as 'permanent participants' to a number of indigenous peoples, including the ICC.

${ }^{v}$ On 1 January 2012, the French Overseas Collectivity in the Caribbean, Saint-Barthélémy, followed the same path as Greenland. A couple of the Dutch Caribbean islands and French Mayotte on the east coast of Africa are currently moving in the opposite direction: from OCT status to full inclusion under the EU acquis.

${ }^{\mathrm{vi}}$ The protocol to the European treaties - known as 'The Greenland Treaty', along with other documents that in conjunction comprise the legal relationship between Greenland and the EU, is available via http://eu.nanoq.gl/Emner/EuGl.aspx, accessed 18 September 2011. For a more detailed account of the development of the legal relations, see Gad (2012).

${ }^{\text {vii }}$ The economic transfer which was the result of the negotiation was, on the one hand, so large that it surprised some of those who had wanted to remain in the EU (Lauritzen, 1997[1984]: 289f). On the other hand, others argued that the fish sold would have produced more revenue had they been processed by the developing Greenlandic fisheries industry (Skydsbjerg, 1999: 26).

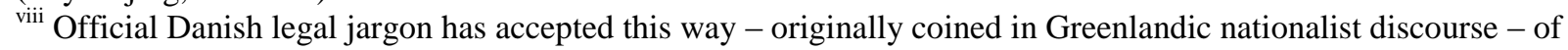
characterizing the transfer of competencies from Denmark to the Home Rule governments in Greenland and the Faroe Islands.

${ }^{\text {ix }}$ Former Greenlandic official, interviewed in Copenhagen (17.12.2010).

${ }^{\mathrm{x}}$ Then Prime Minister Kuupik Kleist, Government of Greenland, interviewed by telephone (28.03.2011).

${ }^{x i}$ General debates on the EU relations have been scheduled a couple of times since then but have been cancelled due to one of the frequent Greenlandic changes in government. For the first 30 years of home rule, the changes always served to keep power from changing: having placed itself in the middle of both a traditional left/right axis and a pro-/antiDenmark axis, the social democratic party Siumut was always in charge, allying itself with varying partners. Since 2009 , however, a coalition government has been formed to keep Siumut out of power. The coalition is lead by the IA party - originating in the left-wing youth rebellion against Danish rule and EC membership - and includes the most
} 
ardent proponents of re-entry; the right-wing Demokraatit. The coalition is based on an agreement to disagree on the EU which has muted political debates on the issue (but see Kristensen, 30.01.2010); an agreement handled in the parliamentary debate on the government's foreign policy strategy in the Fall session of 2011 by focusing on details in the development of the present arrangements rather than the overall relationship to the EU.

xii Palle Christiansen (D), Member of Inatsisartut (24.04.2007).

${ }^{x i i i}$ Per Berthelsen (D), Member of Inatsisartut (24.04.2007).

${ }^{\text {xiv }}$ Josef Motzfeldt (IA), Minister of Finances and Foreign Affairs (24.04.2007).

${ }^{\mathrm{xv}}$ Palle Christiansen (D), Member of Inatsisartut (24.04.2007).

${ }^{x v i}$ Josef Motzfeldt (IA), Minister of Finances and Foreign Affairs (24.04.2007).

${ }^{x v i i}$ Josef Motzfeldt (IA), Minister of Finances and Foreign Affairs (24.04.2007).

${ }^{x v i i i}$ The narrative implies that Greenland's colonial Other - Denmark - needs to be cleared away for Greenland's true identity to be recognized as undisturbed by a better Other (in this case: the EU). A similar role was awarded to the USA in debates over the installation of Missile Defence equipment at Thule Air Base in 2001-02: 'If only we could speak directly to the Americans...' (Gad, 2005: ch.2.2.1). A theoretical basis for analysing the relationship between Greenland and Denmark is explicated in Gad (2005) and (2009).

${ }^{x i x}$ For a detailed argument based on an analysis of Greenland's input to the current process leading to a reform of the OCT arrangements, see Gad et al. (2011) and Hannibal and Holst (2010).

${ }^{\mathrm{xx}}$ As a contrast to how the EU facilitates independent Greenlandic visibility, Greenlandic interviewees mention Canada as a counterpart with a much more sensitive approach to the diplomatic participation of Greenland. The Canadian sensitivity resulted in what is described as an awkward session of 'musical chairs' at a meeting in the margins of a UN general assembly: Canadian diplomats tried to arrange the room for a two-party meeting between the Canadian and the Danish MFA on Arctic policy and other questions of relevance to Greenland, while the Greenlanders - seconded by the Danes - tried to fit a third chair for the Greenlandic MFA into the setup (two Greenlandic officials, interviewed in Copenhagen, 11.01.2011 and 24.02.2011). The Canadian sensitivity probably has to do with a fear of setting a precedence allowing Canada's own home ruled territories a foreign policy presence. For an analysis of Greenland's production of independent visibility in Brussels (and its side effects), see Gad (2012).

${ }^{x x i}$ Two former and present Greenlandic officials, interviewed in Copenhagen and Brussels (17.12.2010 and 24.03.2011, respectively).

${ }^{x x i i}$ In recent years, the active promotion of Greenlandic visibility has been aided by the rising position on the agenda of global warming and related visions of both increased access to natural resources in the Arctic and potentially ensuing conflicts and environmental problems (Strandsbjerg et al., 2011): The EU is currently formulating an Arctic Policy and the Greenlandic officials in Brussels almost feel overwhelmed with invitations to present their positions as everyone seems to want to arrange their own 'Arctic seminar' (three former and present Greenlandic officials, interviewed in Copenhagen and Brussels, 17.12.2010, 28.01.2011 and 24.03.2011, respectively).

xxiii This section builds on 19 formal interviews and a number of informal conversations with diplomats, bureaucrats and politicians from Greenland, Denmark and the EU currently or previously handling the relations between the EU and Greenland. The interviews were conducted in Brussels, Copenhagen and Nuuk in 2009-2011, most face-to-face, a few via the telephone. The reading of the interviews - as well as how they were conducted - was influenced by the 'field work' conducted by the author while employed in the home rule administration in 1998-2001 and 2004. All quotes have been anonymized to secure the anonymity of those interviewees who made this a condition for their participation. A number of the interviews were conducted by Ida Hannibal and Kristine Holst. The author is grateful for being allowed to use their material and being inspired by their analysis reported in (2010). A couple of the interviews were conducted together with Rebecca Adler-Nissen.

${ }^{\text {xxiv }}$ This was a basic tenet in almost all of the interviews in the Greenlandic case - but also in interviews on other OCTs (Hannibal and Holst, 2010). Cf. Petersen (2006: 12f).

${ }^{x x v}$ Even if this 'filter' has been unable to identify all of the potential problems, let alone defuse them (cf. the case of the EU ban on the import of sealskin discussed below).

${ }^{x x v i}$ Greenlandic official, interviewed in Denmark (12.01.2011).

xxvii Three former and present Greenlandic officials interviewed in Copenhagen (17.12.2010, 12.01.2011 and 24.03.2011)

${ }_{\text {xxviii }}$ Former Greenlandic official, interviewed in Copenhagen (17.12.2010).

${ }^{x x i x}$ Former Greenlandic official, interviewed in Copenhagen (02.10.2009).

${ }^{\mathrm{xxx}}$ Kristensen (2004) analyses how Greenland has successfully engaged in a 'politics of embarrassment' in relation to Denmark in relation to the US use of the Thule Air Base: Greenlandic reference to past colonial wrongs made it impossible for Denmark to deny both participation in negotiations with the US and specific side payments.

${ }^{x x x i}$ Greenlandic official, interviewed in Copenhagen (12.01.2011).

${ }^{x x x i i}$ Former Greenlandic official, interviewed in Copenhagen (02.10.2009). 
xxxiii Danish official, interviewed in Copenhagen (14.09.2009).

xxxiv Three Danish and Greenlandic officials, interviewed in Copenhagen and Brussels (14.09.200., 12.01.2011 and 24.03.2011).

${ }^{\mathrm{xxxv}}$ Sealskin (and in parallel whaling, etc.) arguably also has importance for the household budgets of some individual Greenlanders living off subsistence and/or subsidized hunting and fishing.

${ }^{x x x v i}$ Kuupik Kleist (IA), then Chairman of the Naalakkersuisut (prime minister), speaking in Inatsisartut (parliament) (16.06.2009). A Danish diplomat commenting anonymously on the considerations was quoted to say that 'If the government of Greenland decides to challenge the EU decision [in the WTO], it will be Denmark that lodges the appeal on behalf of Greenland. This would result in Denmark, itself a member of the union, suddenly being in the position of lodging an appeal against itself. It is something we have never experienced before and would be extremely unusual' (Sermitsiaq, 28.07.2009).

xxxvii Greenlandic official, interviewed in Copenhagen (12.01.2011). Norway supports Canada in the case, which is still pending at the WTO Dispute Settlement Board as no. DS401.

(http://www.wto.org/english/tratop_e/dispu_e/cases_e/ds401_e.htm, accessed 02.10.2012).

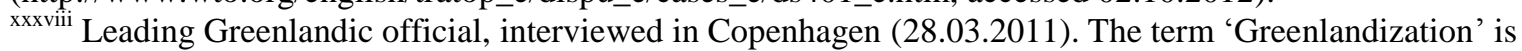

notoriously polyvalent. It involves at least the formal transfer of decisions and administration from Copenhagen to

Nuuk - but may as a programmatic slogan also involve linguistic, ethnic and mental changes (Tobiassen, 1995; Gad, 2008: 121-122).

${ }^{x x x i x}$ Informal conversations with three Danish and Greenlandic officials in Copenhagen (15.03.2011), Brussels (24.03.2011) and Nuuk (17.04.2011).

${ }^{\mathrm{xl}}$ Five present and former Danish and Greenlandic officials, interviewed in Copenhagen and Brussels (09.09.2009, 17.12.2010, 28.01.2011 and 24.03.2011). High profile cases involving 'wild animals' produce work on both sides as well as in Nuuk and Copenhagen.

${ }^{x l i}$ Leading Greenlandic official, interviewed in Copenhagen (28.03.2011).

xlii Commission official, interviewed in Brussels (24.03.2011). 